\title{
ECONOMIC GROWTH AND TAX-COMPETING LEVIATHANS
}

\author{
MiCHAEL RAUSCHER \\ CESIFO WORKING PAPER NO. 1140 \\ CATEGORY 1: PUBLIC FinANCE \\ FEBRUARY 2004
}

An electronic version of the paper may be downloaded

- from the SSRN website:

- from the CESifo website:

www.SSRN.com

www.CESifo.de 


\title{
ECONOMIC GROWTH AND TAX-COMPETING LEVIATHANS
}

\begin{abstract}
Is tax competition good for economic growth? The paper addresses this question by means of a simple model of economic growth in which a wasteful Leviathan state sets taxes and provides productive input. Wasteful behaviour is restricted by the voter, who reduces political support if her income is reduced. The intensity of tax competition is modelled via variation of a parameter measuring the mobility of the tax base. It is shown that the effects of increased mobility of the tax base on economic growth are ambiguous and that the elasticity of intertemporal substitution, which in this model equals the rate of intratemporal substitution between the government's own consumption and its political support, is a decisive variable in this context.
\end{abstract}

JEL Classification: D72, D73, F43, H21.

\author{
Michael Rauscher \\ Institut für Volkswirtschaftslehre \\ Universität Rostock \\ D- 18051 Rostock \\ Germany \\ michael.rauscher@wisofak.uni-rostock.de
}

A draft version of the model investigated in this paper was presented in a seminar at the University of Helsinki and at the 2003 DEGIT conference in Tuusula, Finland. I thank Tapio Palokangas and other participants for helpful suggestions and critique. Financial support by the Deutsche Forschungsgemeinschaft though their SPP 1422 programme on Institutional Design of Federal Systems is gratefully acknowledged. The responsibility for what emerged from all the support is solely mine. 


\section{The Issue}

The economist's perception of the role of the state in the economy is somewhat ambivalent. On the one hand, even free-market advocates concede that government is necessary to provide public goods and in particular the institutional framework without which markets would not function. On the other hand, it is claimed that governments often do too much and that a large government sector produces significant inefficiencies. Pessimists draw the picture of a Leviathan state, which intervenes into functioning markets, substitutes inefficient bureaucracies for well-functioning market processes, and allows its employees to enjoy safe jobs with high pay and little work. ${ }^{1}$ One may interpret the Leviathan as the public-sector equivalent of the $\mathrm{X}$-inefficient firm described by Leibenstein (1966) as an enterprise which does not produce on the edge of its production possibility frontier. Why do voters tolerate this waste of resources? Downs (1957) argues that it is costly for the voter to be informed about the details of the system of government and in particular about the organisation of public administration. Voters are rationally ignorant and do not exert sufficient control over the government. This gives policy makers and bureaucrats a large degree of discretion which they use to follow their own goals, e.g. having safe jobs with high pay and little work. The prodigal Leviathan state becomes a virtually inevitable consequence of the system of representative democracy. How can this process be reversed or at least mitigated?

It has been argued by Brennan/Buchanan (1980), in particular Chapter 9, and others that increased competition for mobile factors of production may help to solve the Leviathan problem. Owners of factors of production are sensitive to public-sector inefficiencies and, ceteris paribus, tend to locate their factors in jurisdictions where taxes are low and public-sector services are good. Since immobile voters suffer from factor dislocation, they will become dissatisfied with their governments and deprive policy makers of their political support. Politicians, who want to be re-elected, are forced to provide better conditions for mobile factors of production by offering better services at lower taxes. Their discretion is reduced and the Leviathan is tamed. This has

1 Note that the original Hobbesian Leviathan by no means was a system of government characterised by the waste of resources. Hobbes characterised a legitimate strong state whose omnipotence was justified by the conviction that other systems of government would lead into anarchy. 
been analysed by Edwards/Keen (1996) and Rauscher (2000) and the result was ambiguous. On the one hand, competition indeed increases the pressure on the state to use its tax revenues more efficiently. On the other hand, the increased mobility of the tax base induces fiscal externalities and under-provision of public-sector services. The latter effects may offset the taming-of-Leviathan effect.

This paper is an attempt to extend the analysis to a dynamic framework. The question posed here is: does increased competition for mobile factors of production force the Leviathan state to change its policies such that higher growth rates are achieved? One could argue that lower taxes and better public-sector services do lead to faster economic growth. The paper shows that this just one possible outcome. Depending on the parameters of the model, more competition may also reduce economic growth rate.

The paper is in the tradition of the optimum-taxation-and-growth literature induced by Judd (1985). Judd derived the result that taxes on capital go to zero in the long run - even in situations in which the government is strongly biased towards workers' interests. A caveat has been raised by Lansing (1999), who shows that Judd's results are based on the implicit premise of the availability of lump-sum or consumption taxes collected from the capital owners. There are several other possibilities to achieve deviations from Judd's zero-tax result. See Lansing (1999, pp. 427-428). This paper, too, comes to the conclusion that capital taxes are not zero and we are able to show that there are three components of this effect. One of them is related to the argument put forward by Lansing (1999). A second one is based on the possibility that governments and private investors have different utility functions. The third one is related to limits on lump-sum taxation of workers.

The literature on tax competition and growth is small. The great difficulty seems to be that optimising governments use private-sector first-order conditions as constraints. This implies that second derivatives show up in the optimality conditions. In static models of tax competition, e.g. those surveyed by Wilson (1999), this problem has been solved. In dynamic growth models matters are often less simple as this paper will show. If one is concerned with benevolent governments and purely redistributive taxation, models can be designed such that those second derivatives cancel out. One of 
the simplifications needed to achieve this is that workers do not save. Moreover, governments should be benevolent. This is in the tradition of Judd (1985). The approach has been applied to tax competition by Lejour/Verbon (1997), who look at a twocountry model. Besides the conventional negative fiscal externality of low taxes, resulting from the competition for a mobile tax base, they identify a positive growth externality. Low taxes in one country increase the growth rate in the rest of the world. If the second effect dominates, uncoordinated taxes will be too high. This contrasts the finding of the standard static tax-competition models that taxes tend to be too low. Razin/Yuen (1999) look at a more general model that also includes human-capital accumulation and endogenous population growth. They come to the conclusion that optimum taxes should be residence-based, capital taxes should be abolished along a balanced growth path, and taxes will be shifted from the mobile to the immobile factor of production if the source principle is applied in a world of tax-competing jurisdictions. Their results extend those derived by Judd (1985) and are in accordance with the standard economic intuition. The underlying assumption is that the government's set of tax instruments is large enough such that distortion-free taxation becomes feasible. We will leave this modelling framework by making the following assumptions:

(a) The set of instruments is restricted and distorting taxes become desirable.

(b) The government is not benevolent, but rather acts as a selfish utility maximiser.

(c) Taxation is not purely redistributive. The public sector provides productive inputs.

The paper is organised as follows. The following section 2 will present the building blocks of the model. There is a private sector consisting of immobile workers and mobile capital owners. The state is a prodigal Leviathan maximising the sum of the voter's and its own well-being. Section 3 solves the model and derives comparativestatic results. The parameter which is varied is an index of interjurisdictional capital mobility that measures the intensity of interjurisdictional competition. In section 4 , we introduce a restriction on labour taxes to be able to compare the results of the dynamic growth model to those known from the literature on static models of tax competition. Finally, section 5 summarises the results and makes some remarks on future research. 


\section{Elements of a Model of Tax Competition and Growth}

\subsection{Definition of Variables and Characterisation of Technology}

Let us consider a federation consisting of a continuum of infinitely small identical jurisdictions, also labelled 'regions', on the unit interval. There is perfect competition in all markets and single jurisdictions do not have any market power vis-à-vis the rest of the federation. The private sector takes prices and policies announced by regional governments as given. Regional governments take variables determined on the federal level as given. There are three factors of production: capital, labour, and a publicly provided input, denoted $K^{i}(t), L^{i}(t)$, and $G^{i}(t)$, respectively. The superscript represents a particular jurisdiction $i$ and $t$ denotes time. Let the production function be defined such that output $Q^{i}(t)$ is

$$
Q^{i}(t)=\Phi\left(K^{i}(t), G^{i}(t), L^{i}(t)\right)=A\left(K^{i}(t)\right)^{\alpha}\left(G^{i}(t)\right)^{1-\alpha}\left(L^{i}(t)\right)^{1-\alpha} .
$$

Regarding the factors of production, the following assumptions are made.

- Labour. Let the labour supply be inelastic and constant and choose units such that $A\left(L^{i}(t)\right)^{1-\alpha}=1$. Thus,

$$
Q^{i}(t)=\left(K^{i}(t)\right)^{\alpha}\left(G^{i}(t)\right)^{1-\alpha} \equiv F\left(K^{i}(t), G^{i}(t)\right)
$$

- Capital. $K^{i}(t)$ denotes a composite capital good consisting of physical capital, human capital, and knowledge capital. Initially, each jurisdiction is endowed with $K^{i}(0)=K_{0}$. The capital stock changes over time due to accumulation. Moreover, capital can move from one jurisdiction to another. Let $K^{*}(t)$ denote the total capital stock of the federation. Then:

$$
\int_{0}^{1} K^{i}(t) d i=K^{*}(t) .
$$

Since jurisdictions are identical, they will - ex post - employ identical capital stocks. Ex ante, however, they may aim at changing the interregional distribution of capital by choosing appropriate policies. However at the end of the day, each regional government finds out that the policy makers in the other jurisdictions of the federation have taken the same actions and that the allocation of capital across 
regions remains unchanged: $K^{i}(t)=K^{*}(t)$. Since jurisdictions are identical, the superscript $i$ can be dropped such that ex post:

$$
K(t)=K^{*}(t) .
$$

$K(t)$ denotes the capital stock employed in an individual jurisdiction, $K^{*}(t)$ the capital employed in the representative jurisdiction of the federation. Ex post, they are equal. Ex ante they may differ.

- The public-sector input. The government provides a productive input at a rate $G(t)$. This may be interpreted as physical infrastructure such as roads and ports, but also institutional infrastructure including the legal framework in which economic transactions take place. For the sake of simplicity, we treat this good as a flow rather than a stock variable. It may be a public good but it does not have to. Interjurisdictional spillovers are excluded. The provision of the public input is financed by taxes. There are two types of taxes, a lump-sum tax $\Theta(t)$ paid by the immobile factor of production and a source tax on capital, $\theta(t) .^{2}$ The implementation of taxes and the behaviour of the public sector will be discussed in more detail later.

\subsection{The Private Sector}

There are two types of individuals in a jurisdiction, capital owners and workers, both types being homogenous and large in number. We assume that capitalists do not work and workers do not own capital. Workers consume all their income, whereas capitalists do save. This assumption is often used in the literature. See Judd (1985) and Lejour and Verbon (1997), for instance. In order to save on notation and to avoid the introduction of a capital market into the model, it is assumed that capitalists are producers as well. Considering capital owners and producers separately would not change the results nevertheless. Finally, producer-capitalists differ from workers in an important respect. Unlike workers, they can choose to live where they want. In the case

2 Other papers like Judd $(1985,1999)$ and Lejour/Verbon (1997) introduce taxes on capital income rather than on capital itself. But as long as taxation is linear, the two instruments are equivalent. 
of labour, the factor cannot be separated geographically from its owner. Capitalists, in contrast, do not have to live where their capital is employed. In our model, they are perfectly mobile. If they are not satisfied with their domicile, they simply dislocate to another jurisdiction which offers better conditions. They vote with their feet like in Tiebout (1956). The only difference compared to the Tiebout world is that in our model mobile capitalists-producers do not demand public goods in the jurisdiction they choose. Thus, they are not willing to pay taxes at their place of residence and in a competitive world with many jurisdictions, they do not pay taxes at their place of residence. Hence, producer-capitalists can only be taxed at source. Perfect mobility has yet another implication for the model. Since mobile capital owners can vote with their feet, they are not interested in participating in the political process. They do not show up at the ballot box and, thus, their interests are not taken into account by the policy maker. This has implications for the specification of the policy maker's objective function that will become obvious later on.

A representative producer-capitalist maximises the present value of her utility. Utility is derived from consumption, $C(t)$, only and is of the CES (constant elasticity of substitution) type with $\varsigma$ being the rate of intertemporal substitution. The discount rate, $\rho$, is positive and constant and the time horizon is infinite. Thus, the individual's objective is to maximise

$$
\int_{0}^{\infty} \frac{(C(t))^{1-\frac{1}{\varsigma}}-1}{1-\frac{1}{\varsigma}} e^{-\rho t} d t
$$

subject to

$$
\dot{K}(t)=\Phi(K(t), G(t), L(t))-w(t) L(t)-\theta(t) K(t)-C(t),
$$

where a dot above a variable denotes its time derivative and $w(t)$ is the wage rate, which is exogenous to the decision maker. The control variables are $C(t)$ and $L(t)$.

For the remainder of this paper, let us omit arguments of functions for notational convenience and let subscripts denote partial derivatives of functions. It is known that the problem at hand has the solution

$$
\begin{aligned}
& \Phi_{L}=F-K F_{K}=w, \\
& \dot{C}=\varsigma\left(F_{K}-\theta-\rho\right) C .
\end{aligned}
$$


Marginal labour productivity equals the wage rate, and the consumption growth path is determined by Ramsey's rule of optimum saving, modified slightly to account for capital taxation. See Judd (1985), for example. Since $F(K, G)$ is a constant-returns-toscale function and $G$ is a variable input, we can look at a balanced growth path along which

$$
\dot{K}=\varsigma\left(F_{K}-\theta-\rho\right) K
$$

For the interpretation of some of the results in the following sections of the paper, we need the consumption-capital ratio along the balanced growth path for the case of $\theta=0$. Taking into account the first-order condition for labour, the state equation, (2), can be rewritten:

$$
\dot{K}=K F_{K}-\theta K-C,
$$

Setting $\theta=0$ and using (3) to eliminate $\dot{K}$, we obtain

$$
\frac{C}{K}=(1-\varsigma) F_{K}+\varsigma \rho \quad \text { if } \quad \theta=0 .
$$

\subsection{Capital Mobility}

Equation (3) determines the accumulation of capital in a closed economy. However, we are interested in tax competition and its effects on economic growth. Tax competition requires openness and, in particular, mobility of a part of the tax base. For the derivation of comparative static results, a parameter measuring the degree of mobility should be part of the model. The literature offers basically two ways introducing such a measure of mobility into the model.

- One could assume that parts of the capital stock can be shifted across jurisdictions at each point in time and that doing so is costly. Nevertheless, discrete jumps in the capital stock of a jurisdiction can occur and in continuous time this corresponds to an infinite investment. This is a basic logical flaw of the approach. Moreover, its simplest and, therefore, most tractable version does not help. If the cost function is symmetric around zero and continuous, e.g. quadratic, the marginal cost at zero is nil. Since in a federation with identical jurisdictions the equilibrium investment is zero, the marginal cost is zero, too, and the parameter that could measure mobility 
vanishes. A solution to this problem has been suggested by Lejour and Verbon (1997), who use an asymmetric quadratic cost function and allow for bi-directional foreign direct investments. The equilibrium is characterised by negative mobility costs and a capital allocation such that each capitalist has invested $x$ percent of her capital stock outside her own jurisdiction. Doing comparative statics is possible, however only at the cost of reduced tractability since three types of capital (domestic capital at home, domestic capital abroad, and foreign capital at home) have to be distinguished. Still the approach suffers from the logical flaw that crossborder direct investment is not modelled as a flow, but as a stock variable.

- The second approach introduces a second state variable, foreign assets, and assumes that foreign direct investment is a flow variable. Capital is not perfectly melleable; investment is costly. Following Hayashi (1982) and Blanchard/Fischer (1989), ch. 2.4., one can introduce installation costs that impede large capital investments. The problem with this approach is the additional mathematical complexity resulting from two additional differential equations. The first one describes the accumulation of a stock of foreign assets and the second one the development of investment flows along the optimal path. Both of them enter the policy maker's objective function as constraints.

Here we choose a third way. The capital accumulation equation, (3), is augmented by a mobility term which is economically intuitive and reasonable, but nonetheless lacks an explicit derivation from profit-maximising behaviour. A jurisdiction attracts capital from the rest of the federation if the rate of return to investment at home, $F_{K}-\theta$, is larger than the rate of return abroad, $r^{*}$. Ex post, $F_{K}-\theta=r^{*}$, but ex ante the regional government may try to attract additional capital by reducing the tax rate or by improving the supply of government inputs. The size of the flow of capital into or out of the region depends on an adjustment or mobility parameter and on the sizes of the capital stocks at home and in the rest of the federation. We model a gravity relationship predicting that foreign direct investment flows are increasing in the capital stocks accumulated in the jurisdiction itself and in the rest of the federation. Let this size effect be denoted by a function $\phi\left(K, K^{*}\right)$, increasing in both arguments and exhibiting constant returns to scale such that (with units appropriately chosen) $\phi(K, K)=K$. Let $\gamma$ 
be the adjustment parameter measuring the flexibility of capital. If this parameter is zero, the economy is autarchic and capital does not move. If it goes to infinity, the rate of investment goes to infinity or - in other words - the capital stock jumps to its equilibrium level such that $F_{K}-\theta=r^{*}$ instantaneously. The model then converges to the class of model known from static tax competition literature where foreign direct investment is modelled as a stock variable. Thus, equation (3) changes to

$$
\dot{K}=\varsigma\left(F_{K}-\theta-\rho\right) K+\gamma\left(F_{K}-\theta-\rho\right) \phi\left(K, K^{*}\right) .
$$

Of course, foreign direct investments should generate returns to the domestic capital owner. However, since capital owners are footloose, their incomes are not part of the policy maker's objective function. They are outside of the model and do not have to be considered in the remainder of the analysis.

\subsection{The Leviathan}

Real-world governments are not benevolent. The assumption of welfare-maximising politicians is useful in models designed to answer normative questions: how should the government behave and which policy measures should it employ? Here we pose the positive question of how governments and public-sector bureaucracies do behave. Like all other actors in the economy, policy makers and bureaucrats are selfish utility maximisers. They act as agents of a principal: the voter. The control of the agents by the principal is, however, imperfect. Voters are rationally uninformed about the details of the conduct of public policy. See Downs (1957). Therefore, policy makers and publicsector bureaucrats enjoy discretion, which they use to follow their own objectives. This may result in biased policies, salaries exceeding marginal productivity, leisure on the job, unproductive status-seeking in public-sector bureaucracies and other activities that informed voters would perceive as a waste of tax money. The complex and multifaceted set of wasteful activities is operationalised in our analysis by simply assuming that the public sector consumes a part of its budget $R(t)$.

$$
R=\Theta+\theta K-G
$$

where $\Theta$ is the tax revenue from lump-sum taxes, $\theta K$ that from source taxes on capital, and $G$ the productive government expenditure. This way of modelling the Leviathan 
was introduced by Brennan/Buchanan (1989), Ch. 2, and used in tax competition models by Edwards/Keen (1996) and Rauscher (2000). ${ }^{3}$ Note that $R$ is not a budget surplus. To the public-sector employee it is a rent; to the voter it is a waste of resources. The budget is balanced in every period. It may be argued that in an intertemporal model, the government should have an intertemporal budget constraint. This case will be discussed towards the end of the paper. Nonetheless, in reality governments are usually constitutionally restricted in their borrowing. The European Stability and Growth Pact of 1997 is just one example and on the sub-national level the constraints on public borrowing are even tighter. Equation (6) is a simplified way of modelling such constraints

Voters may be ignorant concerning the details of the government budget, but they can distinguish a good government from a bad government. They simply look into their purses. A good government implements policies that help people to achieve high incomes and living standards. A bad government fails to do so. Thus, everything else being equal, the higher the income, the better is the government in the perception of the voter and the larger is the degree of political support it can enjoy. In our model, capital owners vote with their feet and, therefore, are irrelevant for political support. What matters are the incomes of the owners of the immobile factor of production. Thus we take labour income,

$$
Y=F-K F_{K}
$$

as a measure of political support.

Let $u(.,$.$) be the government's utility function, with the rent, R$, and labour income, $Y$, as its arguments. Assume $u_{R}>0, u_{Y}>0, u_{R R}<0, u_{Y Y}<0$ and, for the sake of simplification, $u_{R Y}=0$. To keep the model tractable, the utility function is calibrated as a CES function:

$$
u(R, Y)=\frac{R^{1-\frac{1}{\sigma}}-1}{1-\frac{1}{\sigma}}+\frac{Y^{1-\frac{1}{\sigma}}-1}{1-\frac{1}{\sigma}}
$$

3 Qian and Roland (1998) look into the black box of the Leviathan state and model the waste of public resources as an incentive and supervision problem in public hierarchies. 
$\sigma$ is the elasticity of substitution between rent appropriation and political support. At the same time, it is the elasticity of intertemporal substitution, which has a decisive impact on the growth rate the government wants to achieve. The government maximises the present value of future utility discounted at a positive rate $\delta$. Note that neither the discount rate nor the intertemporal elasticity of substitution must equal those of the private sector. E.g., self-interested policy makers may be much more short-sighted than private investors. This would imply $\delta>\rho$. Moreover, there is no reason to expect that the intertemporal elasticities of substitution are equal in the private and the public sectors. Thus, in general $\sigma \neq \varsigma$. The policy maker's objective is to maximise

$$
\int_{0}^{\infty} u(R, Y) e^{-\delta t} d t
$$

with respect to the tax rates, $\Theta, \theta$, and provision of the public-sector input $G$, subject to the state equation, (5), and the initial condition that $K(0)=K_{0}$.

\section{Solving the Model}

It should be noted that all jurisdictions face the same optimisation problem and solve it in the same way. Thus, the results derived for an individual jurisdiction generalise to the federation as a whole. The current-value Hamiltonian of the individual government's optimisation problem is

$$
\begin{aligned}
H= & u\left(\Theta+\theta K-G, F-K F_{K}-\Theta\right) \\
& +\lambda\left[\varsigma\left(F_{K}-\theta-\rho\right) K+\gamma\left(F_{K}-\theta-r^{*}\right) \phi\left(K, K^{*}\right)\right]
\end{aligned}
$$

with $\lambda$ being the costate variable of capital. The canonical equation is

$$
\dot{\lambda}=\left(\delta-\varsigma\left(F_{K}-\theta-\rho\right)-(\varsigma+\gamma) F_{K K} K\right) \lambda-\theta u_{R}+K F_{K K} u_{Y},
$$

Note that we have inserted the conditions of the ex-post equilibrium, $F_{K}-\theta-r^{*}=0$ and $\phi\left(K, K^{*}\right)=K$, already. The first-order conditions are

$$
\begin{aligned}
& u_{R}=u_{Y}, \\
& u_{R}=(\varsigma+\gamma) \lambda, \\
& u_{R}=\left(F_{G}-K F_{K G}\right) u_{Y}+(\varsigma+\gamma) F_{K G} \lambda,
\end{aligned}
$$


In (10c), the condition that $\phi\left(K, K^{*}\right)=K$ ex post, has been used again. Equation (10a) can be rewritten:

$$
\frac{u_{R}}{u_{Y}}=1
$$

The marginal rate of substitution between the rent and political support equals one. This is intuitive since one unit of rent costs one unit of political support if it is financed by lump-sum taxes. Using (10a) and (10b) in equation (10c) yields

$$
F_{G}=1
$$

The marginal productivity of the public-sector input equals 1 . This is straightforward since each unit of this good costs one unit of consumable income. Thus, equation (11) is nothing else but the condition that the marginal value product of a factor equals its price. Thus we have

\section{Proposition 1}

In the first best, the provision of the public input is efficient in the sense that its marginal productivity equals its marginal supply cost.

As a corollary from $F_{G}=1$, we have under constant returns to scale that $F_{K}$ is constant. $^{4}$

Since the production function exhibits constant returns to scale in the variable factors, the outcome of a model is a balanced growth model in which variables grow at the same rate, $g$. Let a hat above a variable represent its growth rate. Thus, we have

$$
g=\hat{K}=\hat{G}=\hat{\Theta}=\varsigma\left(F_{K}-\theta-\rho\right) .
$$

In the steady state and the tax rate, $\theta$, is constant.

It follows from (10b) that that in the steady state $\hat{\lambda}=\hat{u}_{R}$. Then combining (9) and (12) we have

4 Under constant returns to scale, the factor-price frontier is fixed. Since it is monotonous (it is decreasing of course), $F_{K}$ is determined uniquely if $F_{G}$ is determined. 


$$
-\frac{\varsigma}{\sigma}\left(F_{K}-\theta-\rho\right)=\delta-\varsigma\left(F_{K}-\theta-\rho\right)-(\varsigma+\gamma) K F_{K K}-\theta \frac{u_{R}}{\lambda}+K F_{K K} \frac{u_{Y}}{\lambda}
$$

Using the first-order conditions to eliminate $u_{R} / \lambda$ and $u_{R} / \lambda$ and rearranging terms, we arrive at

$$
\theta=\frac{\varsigma(1-\sigma)\left(F_{K}-\rho\right)+\sigma \delta}{\varsigma+\sigma \gamma}
$$

In the case of a closed economy $(\gamma=0)$, this tax rate is modified such that

$$
\theta_{0}=(1-\sigma)\left(F_{K}-\rho\right)+\frac{\sigma}{\varsigma} \delta
$$

Unlike in many other models of capital taxation and growth, the resulting capital tax rate is not zero. There are two sources of this deviating result. On the one hand, the government cannot tax capital owners lump-sum. Thus, source-based taxes have to be used although they distort the accumulation of capital. See Lansing (1999), who has shown this in a somewhat different modelling framework. On the other hand, the preferences of a Leviathan government may deviate systematically from those of the private sector. Thus, policy makers are tempted to use distorting taxes to manipulate the growth rate. E.g., if it has a higher discount rate than private investors, it is less interested in future accumulation of capital and in economic growth than the private sector. Capital accumulation can be reduced by raising the tax rate. For a myopic government such a policy is beneficial since this raises tax revenue, political support, and public-sector consumption in the initial periods. This explains why the optimum tax rate is unambiguously increasing in $\delta$. See equation (13'). Moreover, it can be seen from this equation that the adjustment-speed parameter $\gamma$ has a dampening effect on the tax rate: $s g(d \theta / d \gamma)=s g(-\theta)$. This is also intuitive since larger capital mobility reinforces capital movements that could - ex ante - lead to inefficient allocations of capital across jurisdictions if distorting taxes are used. If the adjustment parameter goes to infinity, i.e. if capital becomes perfectly mobile, the tax rate goes to zero. This is explained by the fact that the growth rate is determined exogenously as $\varsigma\left(r^{*}-\rho\right)$ in the case of perfect capital mobility. The government of an individual jurisdiction is incapable of influencing this rate. Moreover, taxation of mobile capital for the purpose of generating tax revenue becomes infeasible if capital can flee taxation at zero cost. 


\section{Proposition 2}

The optimum tax rate is increasing in the Leviathan's discount rate. Capital mobility has a dampening effect on the tax rate. If capital is perfectly mobile, the source tax on capital is zero. The impacts of the other parameters are ambiguous.

To separate the two components of the optimum tax rate, consider a situation in which government and private sector have the same discount rate and the same elasticity of intertemporal substitution: $\sigma=\varsigma$ and $\delta=\rho$. Denote the corresponding optimal tax rate by $\tilde{\theta}$ in the general case and $\tilde{\theta}_{0}$ in the autarky case $(\gamma=0)$ :

$$
\begin{aligned}
& \tilde{\theta}=\frac{(1-\varsigma) F_{K}+\varsigma \rho}{1+\gamma} . \\
& \tilde{\theta}_{0}=(1-\varsigma) F_{K}+\varsigma \rho .
\end{aligned}
$$

It is obvious from (14) that this tax component is always positive. A government interested in workers' well-being will always tax capital. Interestingly, $\tilde{\theta}_{0}$ equals the private sector's optimal consumption-to-capital ratio in the absence of taxes. See equation (4). Thus, in a closed economy with $\gamma=0$, the tax revenue collected from the capital owners equals the consumption level that they would have chosen in the absence of taxes. This result differs from that reported by Lansing (1999, p.437), who derives a tax rate of $1 / 2$ for a scenario with logarithmic utility functions in which a benevolent government maximises the welfare of workers. Our result for the Leviathan government with a logarithmic objective function would be $\tilde{\theta}=\rho /(1+\gamma)$. As expected, equation (14) shows that the mobility parameter has a negative effect on $\tilde{\theta}$. If capital mobility increases, the desirability of capital taxes is reduced since they become increasingly distortive.

The other component of the optimum tax rate is due to the government's attempt to influence the economy's growth rate according to its own time preference rate and intertemporal elasticity of substitution. The optimum growth rate from the point of view of the government would be $\sigma\left(F_{K}-\delta\right)$ in a closed economy. From equation (12), one can determine the tax rate necessary to adjust the private sector's rate of accumulation to this desired value. Let this tax rate be denoted by $\theta_{0}^{G}$. 


$$
\theta_{0}^{G}=\left(1-\frac{\sigma}{\varsigma}\right) F_{K}+\frac{\sigma}{\varsigma} \delta-\rho
$$

Here, we only give the result for $\gamma=0$. A derivation of this tax component for the case of imperfectly mobile capital would require the explicit consideration of interjurisdictional flows of factor rewards and therefore a substantial extension of the model. In the case of perfect mobility, the economy's growth rate is exogenously determined by $\varsigma\left(r^{*}-\rho\right)$ and cannot be influenced by any taxes.

The two tax components do not in general add up to the optimal tax:

$$
\theta_{0}^{G}+\tilde{\theta}_{0}=\theta_{0}+(\sigma-\varsigma)\left(F_{K}-\rho\right)+\left(1-\frac{\sigma}{\varsigma}\right) F_{K} \text {. }
$$

Only if the elasticities of substitution are equal, $\sigma=\varsigma$, all terms on the right-hand side except the first one vanish and we have $\theta_{0}^{G}+\tilde{\theta}_{0}=\theta_{0}$. This indicates the existence of a non-trivial interaction effect depending on the ratio of the private and public-sector elasticities of intertemporal substitution.

The growth rate of the economy, $g$, is determined by equation (12), into which (13') can be inserted:

$$
g=\frac{\varsigma \sigma}{\varsigma+\sigma \gamma}\left[(\varsigma+\gamma)\left(F_{K}-\rho\right)-\delta\right]
$$

Differentiation with respect to $\gamma$ yields

$$
\frac{d g}{d \gamma}=\frac{\varsigma \sigma}{(\varsigma+\sigma \gamma)^{2}}\left[(1-\sigma)\left(F_{K}-\rho\right)+\sigma \delta\right]
$$

This implies the following proposition:

\section{Proposition 3}

The effect of increased capital mobility on the growth rate of the economy is ambiguous. It is positive if $\left(\frac{1}{\sigma}-1\right)\left(F_{K}-\rho\right)>\delta$. It is negative if $\left(\frac{1}{\sigma}-1\right)\left(F_{K}-\rho\right)<\delta$ 
Two special cases will be considered:

- If $\sigma=1$, i.e. if the policy maker's objective function is logarithmic, then the growth rate will unambiguously be affected positively by increased capital mobility.

- Assume $F_{K}-\rho>0$, i.e. the economy would grow in the absence of capital taxation. Then, the impact of capital mobility on economic growth is positive if $\sigma$ is small and negative if $\sigma$ is substantially larger than 1 .

The elasticity of intertemporal substitution has yet another interpretation. It does not only measure indicate whether actual and future utility are good substitutes; it also measures the substitutability between rent and political support. If they are good substitutes, then the increase in capital mobility can result in lower economic growth. In order to provide the economic intuition behind this result, one would have to disentangle the elasticities of intertemporal and intratemporal substitution by using a different modelling framework.

\section{A Restraint on Lump-sum Taxes: The Taming of Leviathan?}

Lump-sum taxes are a delicate issue. For reasons of political feasibility, the government may refrain from implementing lump-sum taxes on a large scale. This is the conventional starting point of the literature on tax competition in a static world. See Wilson (1986) and Zodrow/Mieszkowksi (1986) for original contributions and Wilson (1999) for a survey. We will introduce a limit on lump-sum taxation, too. But before doing that, a caveat is necessary. In our model, the governments objective function has two arguments, the rent and, as a proxy for political support, the income of the immobile factor. Usually, the introduction of a restraint on lump-sum taxation is justified by distributional concerns. Here these concerns are, however, taken into account in the objective function already. Increased concern for worker's income should result in a change in the utility function such that a larger weight is attached to labour income. This would lead to an increase in workers' income at the expense of publicsector rent and everything else would remain unchanged. All the results of the previous section are maintained. 
Nonetheless, we will look at a constraint on lump-sum taxes. Of course, it is interesting to do this for reasons of comparison with known static models of tax competition. But it is also possible to justify this restriction on the basis of economic arguments. If, e.g., people dislike taxes per se, then such a restriction would make sense. Moreover, if the taxes on workers' incomes cause deadweight losses that are not taken into account by the model explicitly, then the marginal cost of public funds is increased. ${ }^{5}$ As will be seen shortly, this has the same effect as the restriction on the use lump-sum taxes. We model this by imposing an upper bound, $\bar{\Theta}$ to such taxes:

$$
\bar{\Theta}-\Theta \geq 0
$$

The Hamiltonian is augmented by a Lagrangian term $\xi(\bar{\Theta}-\Theta)$ :

$$
\begin{aligned}
H= & u\left(\Theta+\theta K-G, F-K F_{K}-\Theta\right) \\
& +\lambda\left[\varsigma\left(F_{K}-\theta-\rho\right) K+\gamma\left(F_{K}-\theta-r^{*}\right) \phi\left(K, K^{*}\right)\right]+\xi(\bar{\Theta}-\Theta)
\end{aligned}
$$

Complementary slackness implies

$$
\xi(\bar{\Theta}-\Theta)=0, \quad \xi \geq 0
$$

and if the constraint is binding, $\xi>0$. Thus, first-order condition with respect to the lump-sum tax, $\Theta$ is changed

$$
u_{R}=u_{Y}+\xi \text {. }
$$

It follows that

$$
\frac{u_{R}}{u_{Y}}>1
$$

The opportunity cost of appropriating the rent is increased. The same result would be obtained if $\Theta$ represented a distorting labour income tax: the damage to the private sector of the economy would be larger than the government's revenue and the opportunity cost of public-sector consumption would be raised to a value larger than one.

The other first-order conditions, (10b) and (10c), and the canonical equation, (11), remain unchanged. (10b) and (10c) together imply

$$
\frac{u_{R}}{u_{Y}}=\frac{F_{G}-K F_{K G}}{1-K F_{K G}}
$$

5 An example is the distortion generated by income taxes in the case of inelastic labour supply. 
and it follows that

$$
F_{G}>1 \text {. }
$$

This indicates an inefficient under-provision of public-sector inputs as known from static models of tax competition like Zodrow/Mieszkowski (1986) and Rauscher (2000). ${ }^{6}$ Due to the increase in the marginal cost of public funds, the marginal cost of providing the input is increased. This implies an inefficiently high ratio of private capital to public inputs. The marginal productivity of capital is smaller than without the restriction on $\Theta$ and this has a negative impact on the economic growth rate.

\section{Proposition 4}

A restriction on lump-sum taxation leads to inefficiently low supply of government goods and to an increase in the opportunity cost of the public-sector rent.

In the steady state, two variables need to be determined, the tax rate, $\theta$, and the factor input ratio, $G / K$. The second equation, besides (19), to determine these variables is again (13), which is based on the balanced-growth condition, $\hat{\lambda}=\hat{u}_{R} \cdot{ }^{7}$ Using (10b) and rearranging terms yields

$$
\theta=\frac{\varsigma(1-\sigma)\left(F_{K}-\rho\right)+\sigma \delta}{\varsigma+\sigma \gamma}-K F_{K K} \frac{\sigma(\varsigma+\gamma)}{\varsigma+\gamma \sigma}\left(1-\frac{u_{Y}}{u_{R}}\right)
$$

The first term on the right-hand side of this equation is known from the previous considerations. The second term is due to the limit on lump-sum taxation. It is positive as expected. The restriction on the use of one type of taxation leads to an increased use of alternative tax instruments. Partial differentiation of (21) with respect to $\gamma$ yields

6 Note that the Zodrow/Mieszkowski (1986) result is valid only for a special class of production functions and not generally, as they claim. See Sinn (1997).

7 Note that this requires the additional assumption that $\Theta=0$. Otherwise it would not be possible that all relevant variables grow at the same rate. 


$$
\frac{\partial \theta}{\partial \gamma}=-\sigma \frac{\varsigma(1-\sigma)\left(F_{K}-\rho\right)+\sigma \delta}{(\varsigma+\sigma \gamma)^{2}}-K F_{K K} \frac{\sigma(1-\sigma)}{(\varsigma+\sigma \gamma)^{2}}\left(1-\frac{u_{Y}}{u_{R}}\right)
$$

For a constant factor input ratio, the impact of additional capital mobility on the tax rate is ambiguous. The first term again shows a dampening effect. If this tax component is positive, its derivative is negative and vice versa. The decisive parameter here is the government's elasticity of intertemporal substitution. If $\sigma$ is substantially larger than one, then this component of the tax is increased by additional mobility. Otherwise, it is reduced. As regards the other component of the tax rate, the opposite conclusion is drawn. If $\sigma>1$, the second term is reduced. If $\sigma<1$, this term is increased. This finding corresponds to the result derived by Rauscher (2000) in a static modelling framework. There it was shown that a large elasticity of substitution leads to positive effects of tax competition and a small elasticity leads to negative effects. The intuition behind this result is that tighter competition for the mobile tax base in the absence of lump-sum taxes increases the opportunity cost of rent-seeking. If the elasticity of substitution is large, this leads to a significant reduction of wasteful behaviour and this is good for the economy. The same idea can be applied to our model. Here, the positive effect is a reduction in the tax rate, leading to more growth. The negative effect is an increase in the tax rate, leading to smaller (or even negative) growth.

Note the all these considerations are based on partial derivatives, i.e. under the assumption that the other variables are constant. However, they are not constant, but are themselves affected by a change in the tax rate. Equations (19) and (21) should be considered together and total differentials should be calculated. This is done in the appendix for the Cobb-Douglas case and it is seen that the use of partial derivatives may be misleading. Nonetheless, the results derived in this section of the paper can be summarised as follows. 


\section{Proposition 5}

Under restricted use of lump-sum taxes, the source tax on capital consists of three components

(a) an effect coming from the government's attempt to influence the growth rate,

(b) an effect due to the absence of lump-sum taxation of capital owners, and

(c) an effect due to the absence of lump-sum taxation of workers.

The total effect is ambiguous and the sign of the impact of capital mobility on the tax rate and on economic growth is ambiguous, too. The government's elasticityof-substitution parameter is decisive for the direction of this effect.

\section{Final Remarks}

This paper has looked at the effects of increased interjurisdictional capital mobility on taxation and economic growth. The government was modelled as a prodigal Leviathan. It turned out that the optimal tax on mobile capital is determined by the non-availability of distortion-free taxes and by the deviation of the government's preferences from the private ones. The decisive variable in the determination of the effects on tax rates and economic growth is the intertemporal elasticity of substitution. The general results are ambiguous. Anything can happen. An increase in the intensity of interjurisdictional competition may be growth enhancing or growth decelerating. Some basic intuitions for the results gave been given in the paper.

Of course, the modelling framework is rather simple and neglects many phenomena that are relevant in the real world, e.g. savings by workers, imperfect mobility of capital owners, and public-sector borrowing. In particular, the constraint of an intratemporally balanced government budget is restrictive. Although such assumption can be justified on the grounds that government borrowing is restricted (albeit in a laxer sense than in this model), it might be interesting allow for more flexibility. Modifying the model in this respect would add another determinant of taxation in a closed or imperfectly open economy: governments could use distorting taxes to reduce the interest rate and, thus, relax their intertemporal budget constraints. 
Another extension would be to model the government input as a capital good, i.e. a stock rather than a flow variable. One could also add technological progress in the government sector to ask whether tax competition increases the rate of innovation: does tax competition contribute positively to a modernisation of the public sector? This question is on the agenda for future research.

\section{Appendix: Comparative Statics for the Cobb-Douglas case}

Assume $\Theta=0$. Starting points are the following three equations:

$$
\begin{aligned}
& \frac{u_{Y}}{u_{R}}=\left(\frac{F-K F_{K}}{\theta K-G}\right)^{-\frac{1}{\sigma}}, \\
& \frac{u_{R}}{u_{Y}}=\frac{F_{G}-K F_{K G}}{1-K F_{K G}}, \\
& \theta=\frac{\varsigma(1-\sigma)\left(F_{K}-\rho\right)+\sigma \delta}{\varsigma+\sigma \gamma}-K F_{K K} \frac{\sigma(\varsigma+\gamma)}{\varsigma+\gamma \sigma}\left(1-\frac{u_{Y}}{u_{R}}\right) .
\end{aligned}
$$

The first equation is the marginal rate of substitution derived from the Leviathan's utility function and the other two equations are the steady state conditions. Define

$$
k=\frac{K}{G}
$$

From the Cobb-Douglas function, (1'), we have:

$$
\begin{aligned}
& F=k^{a-1} K, F_{G}=(1-a) k^{a}, K F_{K G}=a(1-a) k^{a}, F_{K}=a k^{a-1}, \\
& K F_{K K}=-a(1-a) k^{a-1} .
\end{aligned}
$$

Using this in the three equations and rearranging terms yields:

$$
\begin{aligned}
& \theta-k^{-1}-(1-a) k^{a-1}\left(\frac{u_{Y}}{u_{R}}\right)^{\sigma}=0, \\
& (1-a) k^{a} \frac{u_{Y}}{u_{R}}+a k^{a}=\frac{1}{1-a}, \\
& \theta-\frac{\varsigma(1-\sigma)\left(a k^{a-1}-\rho\right)+\sigma \delta}{\varsigma+\sigma \gamma}-a(1-a) k^{a-1} \frac{\sigma(\varsigma+\gamma)}{\varsigma+\gamma \sigma}\left(1-\frac{u_{Y}}{u_{R}}\right)=0 .
\end{aligned}
$$

Total differentiation of this system yields: 


$$
\left(\begin{array}{ccc}
1 & -\sigma(1-a) k^{1-a}\left(\frac{u_{Y}}{u_{R}}\right)^{\sigma-1} & k^{-2}+(1-a)^{2} k^{a-2}\left(\frac{u_{Y}}{u_{R}}\right)^{\sigma} \\
0 & (1-a) k^{a} & \left.(1-a) \frac{u_{Y}}{u_{R}}+a\right) a k^{a-1} \\
1 & a(1-a) k^{a-1} \frac{\sigma(\varsigma+\gamma)}{\varsigma+\gamma \sigma} & \left(\varsigma(1-\sigma)+\sigma(\varsigma+\gamma)(1-a)\left(1-\frac{u_{Y}}{u_{R}}\right)\right)(1-a) a k^{a-2} \\
\varsigma+\sigma \gamma
\end{array}\right)\left(\begin{array}{c}
d \theta \\
d \frac{u_{Y}}{u_{R}} \\
d k
\end{array}\right)=\left(\begin{array}{c}
0 \\
0 \\
\frac{\partial \theta}{\partial \gamma} d \gamma
\end{array}\right)
$$

The terms on the matrix on the left-hand side of this equation, denoted $B$, have the following signs:

$$
B \sim\left(\begin{array}{lll}
+ & - & + \\
0 & + & + \\
+ & + & \pm
\end{array}\right) .
$$

Let us denote the $i$ th-row $j$ th-column element of $B$ by $b_{i j}$. We then have

$$
\begin{aligned}
& \frac{d \theta}{d \gamma}=\frac{b_{12} b_{23}-b_{22} b_{31}}{\operatorname{det}(B)} \frac{\partial \theta}{\partial \gamma} \\
& \frac{d \frac{u_{Y}}{u_{R}}}{d \gamma}=\frac{-b_{11} b_{31}}{\operatorname{det}(B)} \frac{\partial \theta}{\partial \gamma} \\
& \frac{d k}{d \gamma}=\frac{b_{11} b_{22}}{\operatorname{det}(B)} \frac{\partial \theta}{\partial \gamma}
\end{aligned}
$$

Thus, the adjoints, displayed as numerators on the right-hand sides of these equations have unambiguous signs. The sign of the determinant in the denominator can be positive or negative. It depends on $b_{33}$. If $b_{33}<0$, then $\operatorname{det}(B)<0$. Otherwise $\operatorname{det}(B)$ can be positive. Given that fact that the other terms determining $\operatorname{det}(B)$ are negative, this is unlikely, but it cannot be excluded.

It can be seen from (A5) and (A7), however, that $d \theta / d \gamma$ and $d k / d \gamma$ have opposite signs. A large tax rate is bad for economic growth. A large ratio of capital per unit of government input implies a low capital productivity and, therefore, is also bad for economic growth. Due to the opposite directions of the two effects, an additional ambiguity in the determination of the impact on economic growth becomes obvious. 


\section{References}

Blanchard, O.J, S. Fischer, 1989, Lectures on Macroeconomics, Cambridge, Mass: MIT-Press.

Brennan, G, J.M. Buchanan, 1980, The Power to Tax: Analytical Foundations of a Fiscal Constitution, Cambridge: Cambridge University Press.

Downs, A., 1957, An Economic Theory of Democracy, New York: Harper and Row.

Edwards, J., M. Keen, 1996, Tax Competition and Leviathan, European Economic Review 40, 113-140.

Hayashi, F., 1982, Tobin's Marginal and Average q: A Neoclassical Interpretation, Econometrica 50, 213-224.

Judd, K.L., 1985, Redistributive Taxation in a Simple Perfect Foresight Model, Journal of Public Economics 28, 29-53.

Judd, K.L., 1999, Optimal Taxation and Spending in General Competitive Growth Models, Journal of Public Economics 71, 1-26.

Lansing, K.J., 1999, Optimal Redistributive Taxation in a Neoclassical Growth Model, Journal of Public Economics 73, 423-453.

Lejour, A.M., H.A.A. Verbon, 1997, Tax Competition and Redistribution in a TwoCountry Endogenous-Growth Model, International Tax and Public Finance 4, 485497.

Leibenstein, H. 1966, Allocative Efficiency vs 'X-efficiency', American Economic Review 56, 392-415.

Qian, Y., G. Roland, 1998, Federalism and the Soft Budget Constraint, American Economic Review 88, 1143-1162.

Rauscher, M., 2000, Interjurisdictional Competition and Public-Sector Prodigality: The Triumph of the Market over the State?, Finanzarchiv 57, 89-105.

Razin, A., C.-W. Yuen, 1999, Optimal International Taxation and Growth Rate Convergence: Tax Competition vs. Coordination, International Tax and Public Finance 6, 61-78. 
Sinn, H.-W., 1997, The Selection Principle and Market Failure, Journal of Public Economics 66, 247-274.

Tiebout, C.M., 1956, A Pure Theory of Local Expenditures, Journal of Political Economy 64, 416-424.

Wilson, J.D., 1986, A Theory of Interregional Tax Competition, Journal of Urban Economics 19, 296-315.

Wilson, J.D., 1999, Theories of Tax Competition, National Tax Journal 52, 269-304.

Zodrow, G.R., P.M. Mieszkowski, 1986, Pigou, Tiebout, Property Taxation, and the Under-Provision of Public Goods, Journal of Urban Economics 19, 356-370. 


\section{CESifo Working Paper Series}

(for full list see www.cesifo.de)

1073 Robert S. Chirinko and Julie Ann Elston, Finance, Control, and Profitability: The Influence of German Banks, November 2003

1074 Wolfgang Eggert and Martin Kolmar, The Taxation of Financial Capital under Asymmetric Information and the Tax-Competition Paradox, November 2003

1075 Amihai Glazer, Vesa Kanniainen, and Panu Poutvaara, Income Taxes, Property Values, and Migration, November 2003

1076 Jonas Agell, Why are Small Firms Different? Managers' Views, November 2003

1077 Rafael Lalive, Social Interactions in Unemployment, November 2003

1078 Jean Pisani-Ferry, The Surprising French Employment Performance: What Lessons?, November 2003

1079 Josef Falkinger, Attention, Economies, November 2003

1080 Andreas Haufler and Michael Pflüger, Market Structure and the Taxation of International Trade, November 2003

1081 Jonas Agell and Helge Bennmarker, Endogenous Wage Rigidity, November 2003

1082 Fwu-Ranq Chang, On the Elasticities of Harvesting Rules, November 2003

1083 Lars P. Feld and Gebhard Kirchgässner, The Role of Direct Democracy in the European Union, November 2003

1084 Helge Berger, Jakob de Haan and Robert Inklaar, Restructuring the ECB, November 2003

1085 Lorenzo Forni and Raffaela Giordano, Employment in the Public Sector, November 2003

1086 Ann-Sofie Kolm and Birthe Larsen, Wages, Unemployment, and the Underground Economy, November 2003

1087 Lars P. Feld, Gebhard Kirchgässner, and Christoph A. Schaltegger, Decentralized Taxation and the Size of Government: Evidence from Swiss State and Local Governments, November 2003

1088 Arno Riedl and Frans van Winden, Input Versus Output Taxation in an Experimental International Economy, November 2003 
1089 Nikolas Müller-Plantenberg, Japan’s Imbalance of Payments, November 2003

1090 Jan K. Brueckner, Transport Subsidies, System Choice, and Urban Sprawl, November 2003

1091 Herwig Immervoll and Cathal O'Donoghue, Employment Transitions in 13 European Countries. Levels, Distributions and Determining Factors of Net Replacement Rates, November 2003

1092 Nabil I. Al-Najjar, Luca Anderlini \& Leonardo Felli, Undescribable Events, November 2003

1093 Jakob de Haan, Helge Berger and David-Jan Jansen, The End of the Stability and Growth Pact?, December 2003

1094 Christian Keuschnigg and Soren Bo Nielsen, Taxes and Venture Capital Support, December 2003

1095 Josse Delfgaauw and Robert Dur, From Public Monopsony to Competitive Market. More Efficiency but Higher Prices, December 2003

1096 Clemens Fuest and Thomas Hemmelgarn, Corporate Tax Policy, Foreign Firm Ownership and Thin Capitalization, December 2003

1097 Laszlo Goerke, Tax Progressivity and Tax Evasion, December 2003

1098 Luis H. B. Braido, Insurance and Incentives in Sharecropping, December 2003

1099 Josse Delfgaauw and Robert Dur, Signaling and Screening of Workers' Motivation, December 2003

1100 Ilko Naaborg, Bert Scholtens, Jakob de Haan, Hanneke Bol and Ralph de Haas, How Important are Foreign Banks in the Financial Development of European Transition Countries?, December 2003

1101 Lawrence M. Kahn, Sports League Expansion and Economic Efficiency: Monopoly Can Enhance Consumer Welfare, December 2003

1102 Laszlo Goerke and Wolfgang Eggert, Fiscal Policy, Economic Integration and Unemployment, December 2003

1103 Nzinga Broussard, Ralph Chami and Gregory D. Hess, (Why) Do Self-Employed Parents Have More Children?, December 2003

1104 Christian Schultz, Information, Polarization and Delegation in Democracy, December 2003

1105 Daniel Haile, Abdolkarim Sadrieh and Harrie A. A. Verbon, Self-Serving Dictators and Economic Growth, December 2003

1106 Panu Poutvaara and Tuomas Takalo, Candidate Quality, December 2003 
1107 Peter Friedrich, Joanna Gwiazda and Chang Woon Nam, Development of Local Public Finance in Europe, December 2003

1108 Silke Uebelmesser, Harmonisation of Old-Age Security Within the European Union, December 2003

1109 Stephen Nickell, Employment and Taxes, December 2003

1110 Stephan Sauer and Jan-Egbert Sturm, Using Taylor Rules to Understand ECB Monetary Policy, December 2003

1111 Sascha O. Becker and Mathias Hoffmann, Intra-and International Risk-Sharing in the Short Run and the Long Run, December 2003

1112 George W. Evans and Seppo Honkapohja, The E-Correspondence Principle, January 2004

1113 Volker Nitsch, Have a Break, Have a ... National Currency: When Do Monetary Unions Fall Apart?, January 2004

1114 Panu Poutvaara, Educating Europe, January 2004

1115 Torsten Persson, Gerard Roland, and Guido Tabellini, How Do Electoral Rules Shape Party Structures, Government Coalitions, and Economic Policies? January 2004

1116 Florian Baumann, Volker Meier, and Martin Werding, Transferable Ageing Provisions in Individual Health Insurance Contracts, January 2004

1117 Gianmarco I.P. Ottaviano and Giovanni Peri, The Economic Value of Cultural Diversity: Evidence from US Cities, January 2004

1118 Thorvaldur Gylfason, Monetary and Fiscal Management, Finance, and Growth, January 2004

1119 Hans Degryse and Steven Ongena, The Impact of Competition on Bank Orientation and Specialization, January 2004

1120 Piotr Wdowinski, Determinants of Country Beta Risk in Poland, January 2004

1121 Margarita Katsimi and Thomas Moutos, Inequality and Redistribution via the Public Provision of Private Goods, January 2004

1122 Martin Peitz and Patrick Waelbroeck, The Effect of Internet Piracy on CD Sales: CrossSection Evidence, January 2004

1123 Ansgar Belke and Friedrich Schneider, Privatization in Austria: Some Theoretical Reasons and First Results About the Privatization Proceeds, January 2004

1124 Chang Woon Nam and Doina Maria Radulescu, Does Debt Maturity Matter for Investment Decisions?, February 2004 
1125 Tomer Blumkin and Efraim Sadka, Minimum Wage with Optimal Income Taxation, February 2004

1126 David Parker, The UK's Privatisation Experiment: The Passage of Time Permits a Sober Assessment, February 2004

1127 Henrik Christoffersen and Martin Paldam, Privatization in Denmark, 1980-2002, February 2004

1128 Gregory S. Amacher, Erkki Koskela and Markku Ollikainen, Deforestation, Production Intensity and Land Use under Insecure Property Rights, February 2004

1129 Yin-Wong Cheung, Javier Gardeazabal, and Jesús Vázquez, Exchange Rate Dynamics: Where is the Saddle Path?, February 2004

1130 Alberto Alesina and Guido Tabellini, Bureaucrats or Politicians?, February 2004

1131 Gregory S. Amacher, Erkki Koskela, and Markku Ollikainen, Socially Optimal Royalty Design and Illegal Logging under Alternative Penalty Schemes, February 2004

1132 David M. Newbery, Privatising Network Industries, February 2004

1133 Charles Yuji Horioka, The Stagnation of Household Consumption in Japan, February 2004

1134 Eiji Fujii, Exchange Rate Pass-Through in the Deflationary Japan: How Effective is the Yen's Depreciation for Fighting Deflation?, February 2004

1135 Mark M. Spiegel and Nobuyoshi Yamori, Determinants of Voluntary Bank Disclosure: Evidence from Japanese Shinkin Banks, Febrary 2004

1136 Robert Dekle and Kenneth Kletzer, Deposit Insurance, Regulatory Forbearance and Economic Growth: Implications for the Japanese Banking Crisis, February 2004

1137 Takatoshi Ito and Kimie Harada, Bank Fragility in Japan, 1995-2003, February 2004

1138 Kunio Okina and Shigenori Shiratsuka, Policy Duration Effect under Zero Interest Rates: An Application of Wavelet Analysis, February 2004

1139 Francine D. Blau and Lawrence M. Kahn, Do Cognitive Test Scores Explain Higher U.S. Wage Inequality?, February 2004

1140 Michael Rauscher, Economic Growth and Tax-Competing Leviathans, February 2004 